\section{Afno Manchhe: Unequal Access to Public Resources and Institutions in Nepal}

\author{
Madhusudan Subedi
}

\begin{abstract}
This paper highlights the informal inner circle network approach to maintaining relationships and reciprocating favors within a system that significantly affect the performance of incumbents in formal bureaucratic organizations. While this is a general sociological problem in any society, this article deals with how afno manche behavior is manifested in Nepal. Without afno manchhe relations, one risks marginalization, disappointments and failures in one's struggle to realize important goals in life. In such a situation, the malfunctioning of administration and dissatisfaction arise at every level. There is thus a significant relationship between one's position in afno manche networks and inclusion-exclusion processes. This of course has consequences for the widespread practice of corruption in Nepal.
\end{abstract}

\section{Keywords: Afno Manchhe, Guanxi, Corruption, Nepotism}

\section{Introduction}

Interest in network studies among social scientists dates back to the 1950 s, but this methodology only really gained prominence in the 1970s, and did not evolve into a recognized approach until the 1980s (Chang 2004). The notion of reciprocity and other relevant ideas are derived from works of earlier anthropologists, such as Marcel Mauss, Bronislaw Malinowski and Raymond Firth. The approach is thus very dynamic and 'provides a convenient, efficient, and most importantly productive way of penetrating to the heart of various social orders'. Here, I relate Bourdieu's (1977) conceptualization of capital within which they are utilized. Symbolic capital, for Bourdieu, consists of the prestige, and renown attached to a family and a name. Symbolic capital is the legitimate way to accumulate resources, and these symbolic resources can themselves be utilized for economic gain. Social capital includes obligation, the advantages of connections or social position, and trust. Economic capital is the most objective, certain, and enforceable. This paper focuses on the interpersonal connections that people use in their day-to-day lives for understanding and interacting with their social environment. People in different sectors of life try to find out some secure inner circle, be it within the kin relationship, business deals or political networking. There are few Nepalis who are willing to leave their own secure inner circle. People who don't belong to one's own inner circle are perceived as being marginal and there is no real concern over what happens to such unrelated individuals.

Afno manchhe is a Nepali term that can be translated as 'one's own people'. It refers to relationships of reciprocal nature with an implicit hierarchy. It may partly be based on ascribed principles derived from kinship and marriage, but most significantly afno manchhe relationships have to be confirmed in symbolic practices expressing the content of the relationship. Afno manchhe relations can thus be strategically developed between people unconnected by kinship and marriage, and afno manche ties between people who are connected by kinship and marriage may be weakened if not confirmed by appropriate symbolic exchanges of gifts, information, and services. Such practices constitute a dominant strategy of human connectivity in Nepal, the daily activities of people and their relationships with one another (Bista 1991). It has the potential of being used to construct an informal personalized organization of activities that affect the operation of formal structures of market and bureaucracy. In practice, 
afno manchhe is not limited to familial relations. It may include people working in the same profession or the same field, business stakeholders or members of a particular organization. The way it has been used in Nepal indicates more than relationship; it may lead to the misuse of power and constitutes a unique path for corruption.

In this sense, it shows a kind of family relationship (in a Wittgensteinian sense) to the Chinese concept of guanxi referring to personal networks of social relations (Haaland 2010). It is a cultural characteristic that has strong implications for interpersonal and interorganizational dynamics in Chinese society. It refers to the concept of drawing on a web of connections to secure favors in personal and organizational relations (Park and Luo 2001). One's life chances in society are to a large extent related to the scale and power of guanxi relations one can mobilize. Such relations are primarily ascribed by birth and involve obligations to exchange gifts, cooperate in economic activities, and support each other in politico administrative activities (Haaland 2010). It is a special relationship between a person who needs something and a person who has the ability to give something (Fan 2002).

Both the terms afno manchhe and guanxi are different cultural constructions for tackling a similar sociological problem, namely the problem of personalization of formal impersonal relations. In both cases, personalization is embedded in cultural values like trust, loyalty, and familism expressed in activities loaded with symbolic meanings. These symbolic constructions differ and afno manchhe can thus not be translated as guanxi, they are different concepts embedded in different cultural universes and with different politico-economic consequences, but are similar in the sense that they refer to a general organizational problem. To what extent afno manchhe in Nepal and guanxi in China are ethical is a particular issue largely ignored in the literature (Fan 2002, Subedi 2005). The favor and networking to maintain the correct connection is not exclusive to Nepal but it has been occurring at an alarming and distinctly defining rate. When many people relying on afno manche, then how can we refrain from doing the same? The problem is how this ethical issue should be addressed: with reference to universal standards of ethics or with reference to concepts of ethics particular to the society in question.

This paper aims to discuss the dimensions of such social connections in performing roles and regards rights, expectations, obligations and responsibilities in a network of relationship. In such a situation, my argument is that the people in everyday day life try to develop afno manchhe relationship strategically to achieve something. It may be honor, material wealth or a special kind of power. In this strategic game, some people would become success and many would fail and get frustrated. Those who have specific knowledge, skilled and qualification but without having such inner circle get frustrated and make plan for brain drain. The sidelines of meritocracy lead to the malfunctioning of development administration and dissatisfaction arises at every level and acquisition of corruption. The series of interactions were done with university teachers, students, development workers, bureaucrats and political cadres to understand such social processes, many events are observed and the news and views expressed by the media are also keenly read. The paper starts with the concept and types of afno manchhe in Nepal, and elaborates the consequences of afno manchhe on individual and organizational spheres. Furthermore, Nepali concept of afno manchhe and Chinese concept of guanxi are compared.

\section{Afno manchhe in Nepal and guanxi in China}

From the time of Nepal's unification in 1769 to the advent of democracy in 1990, the King had a complex power in the country. This power was cultivated over several hundred years. The time of monarchy until recently, all executive, legislative and judicial powers resided with the King and the country was ruled from the palace with the help of courtiers called 'Bhardars' (Pfaff-Czarnecka 1997). A connection with anyone in the palace was almost as good as connection within the social nexus in which the relationship of patronage, reciprocity, and family connection was the basis for privileges, protection, and all manner of rewards. Power in this system 
was lodged in a multiple system of favoritism, each with its own logic but shared sensitibilities of the family-like ties, reciprocity, and access to privilege through social affiliation, preferably ascribed by birth but possible even if acquired through clever procedures of social endearment (Subedi 2001).

The forms of favoritism include giving priority to close relatives (natabad), to those already involved in reciprocal or familylike relationship (kripabad), and to "one's own people" (afno manchhe), flattery or "currying favor" (chakari) and especially cultivating reciprocal obligations with superiors. Chakari was officially introduced by Ranas as a way to keep rivals or opponents from posing a threat. They had pajani system to sack disloyal public servants. Chakari was a way to judge loyalty and reliability with government employees required to perform it to keep their jobs and be promoted. Land was allotted to public officials in return for special favors, the birta system (Regmi 2002). Chakari is constantly visible in Nepal. The employees have to perform chakari to ensure job security and in order to be eligible for promotion, the junior politician have to perform chakari to be appointed in central committee member, and the national level politicians do chakari to the international community and power centre for getting favor in political, economic and ideological issues. This is a vertical relationship. A strong distinction is made between 'us, 'who are trustworthy, loyal, to be helped, and 'them' to whom one has no responsibilities, and who deceive and are to be deceived (Macfarlane 1993). Chakari is institutionalized in bureaucracy, professional association, business organizations and development organizations.

For most Nepalis, using these sort of connections is part of what it means to be a Nepali, for these members of social affiliation situated one in webs of relationship that ultimately tied one to the king-the symbol and body of nation-or to the palace, the place from which most privileges came and which was thought ideally form a microcosm for the ideal of nation (Adam 1998:37). The issues of fairness, equality and accountability were not discussed publicly.
Rather, having special relationship with monarchy and (mis)using power were a matter of pride. Bista (1991), describe the concept of afno manchhe as:

Afno manchhe is the term to designate one's inner circle of associates - it means 'one's own people' and refers to those who can be approached whenever need arises. The strength or weakness of anyone is measured in terms of the quality and quantity of the circles of afno manchhe he is part of. Afno manchhe is a critical Nepali institution.... The most important asset for anyone is not what you know, but who you know (1991:98).

Bista further gives an example of a bank and says that a bankteller takes longer to cash a cheque if the customer is a nonperson, but makes a special effort if the customer is a member of his circle and therefore afno manchhe. The reputation of the bank becomes of secondary importance as the maintenance of the fence around one's own circle is primary. The same thing is true in all government and corporate offices (Bista 1991). If someone has to go to hospital to consult the doctor, seek help from police, admit their children in schools, apply for jobs, the first thing in their mind is who is where and how to get properly connected to them. Sometimes a telephone call from a higher authority or well connected people is enough to get better access to the consultant, responsible behavior of the police, admission and fee reduction in schools and priority for employment.

Being able to take advantage of personal connections through natabad, kripabad or afno manchhe to gain advantage over competitors is called having pahuch or source-force, which involves the exercise of control of power based on their jats, kinship, business or political affiliations. Adam (1998:39) writes, for example:

If one needed any sort of privilege from a ministry, one would consider if one had afno manchhe in that ministry on whom 
one could rely for processing one's request. If no family connection existed, one might consider chakari to create a basis for obtaining favors from a status superior. These family relations were usually the most promising sort of afno manchhe, but beyond that person's who were in one's caste or ethnic group, and after them cultivated friends who could be brought into a morally obliged sense of duty, as would be true in the family, were sought. Thus creating afno manche relationships through marriage, politics, and a multitude of social events (worship events, parties, gambling, social clubs, sports, hobbies, etc) was a primary strategy for economic, political, and social mobility.

Subedi (2001) mentioned that transfer of government officials has a strong link with afno manchhe. Quoting the view of a doctor, who was transferred from one remote area to another for the last eight years, Subedi (2001:139) writes;

Our appointments are based on a person's connection with key decision makers. There is no way to evaluate a doctor who is working alone in a remote area. The doctors who are working in a remote area usually lack source force (political power) and afno manchhe. Doctors with source force and afno manche are better able to stay at Kathmandu where they can take exams and give pressures to the high officials for promotions.

Thus, afno manchhe is multifaceted and negotiated in different contexts. Similarly, in China, the core idea of guanxi involves relationships between or among individuals creating obligations for the continued exchange of favors. It is either a blood relationship or some social interconnections (Dunfee and Warren 2001). One's life chances in society are to a large extent related to the scale and power of the guanxi relations one can mobilize. Such relations are primarily ascribed by birth and involve obligation to exchange gifts, cooperate in economic activities and support each other in politicoadministrative activities (Haaland 2010). This is essentially interpreted as relationships between persons without attention to their contacts with institutions or to relationships between the institutions themselves (Chang 2004). Perhaps the most important and common characteristic of afno manchhe and guanxi is personal but a special relationship which demands a kind of reciprocal obligation. Failure to reciprocate may result in the loss of one's social network and multiple resources embedded in it (Mallington, Eberhardt and Wilkinson 2005, Adams 1998, Subedi 2005). In the Nepali context, it can be said that a network of afno manchhe and its (mis)use in various context are chief features of feudal hierarchy which ignores meritocracy and universalistic values.

According to Yang (1989), guanxi in China is built through the exchange of gifts, favor and banquets. The art of guanxi lies in the skillful mobilization of moral and cultural imperatives such as obligation and reciprocity in pursuit of both diffuse social ends and calculated instrumental ends. The cultivation of guanxi involves more than the negotiation of a deal and usage of customary forms to disguise what might otherwise be recognized as a corrupt and illegal exchange. The exchanges are used to cultivate and strengthen relationships that are expected to continue (Smart 1993).

\section{Formation of Afno Manchhe in Nepal}

The distinction between 'us' and 'them' manifests itself in every walk of social, cultural, political and economic life (Bista 1991). Everything inside one's own circle is predictable and the rest is external and unpredictable. Therefore, there is a constant need to maintain this boundary. The maintenance of inner group is achieved in a number of ways. Gathering people together for ritualistic festive occasion is one. Birthday parties, marriage ceremonies, clan worships, feasts and funeral rites provide a platform for the formation of family or kinship ties. During major festivals like Dasain for Hindus, Buddha Jayanti and special ethnic festivals for Janajatis, people try to develop 
a wider network with people who can manipulate their political, economic and social capital. Special gifts are offered to these powerful people to make the visit more memorable. Powerful people, on the other hand, a more then likely to reciprocate these favors in the future based on the needs and expectations of the giver.

Distributing greeting cards during major festivals is another means to not only define the consistency of one's own circle but also expand it circumferences. This also includes business groups and professional members. Though not a recent phenomenon, it has a very stronghold compared to others, is formation of politically afno manchhe, an ideological value loaded inner circle. Participating in various programs organized by political parties and their sister organizations is one of the main ways for people to try to form direct links with national level political leaders and get into their inner circle. This trend has picked up after the establishment of multi-party democracy in Nepal. However, it is also to be noted that afno manchhe can be formed in other ways like chakari ${ }^{1}$, kin, business and political. Thus, it is a strategy to create relations with those who are more privileged, be it economically or politically, and can provide access.

${ }^{1}$ Chakari is an essential concept which means to wait upon, to serve, to appease, and to seek favor from politically or administratively well off people (Subedi 2005). According to Bista, “Chakari was officially introduced into secular life during the Rana period, mainly as a form of control designed to keep potential rivals or opponents away from belligerent activities. These potential rivals were required to spend time generally in attendance at the Rana palaces, where at certain hours the Rana would be able to observe them physically and know that they were not somewhere else fomenting troubles. This was done very formally, usually in the afternoon, and the hours set aside for this purpose were known as the chakari hours (Bista 1991:90). Those seeking improvement in life via this practice are called chakariwal, people practicing chakari. With the end of Rana rule, chakari was formally abolished, but then it had firmly installed itself as an integral feature of Nepali social organization. Today, chakari remains an integral part of social life and is evident at all levels of government (Subedi 2005).
Afno manchhe is formed strategically, says a young political scientist at Tribhuvan University (TU). He says:

An educated person changes his/her political ideology; departs from one party to another. It is not a simple phenomenon based on ideological understanding, trust and commitment. It is related to his/her long term mission to gain something from that network. To fulfill the mission and acquire something, people change the political party in Nepal. added:

Another political scientist from the same department further

The networks that you build with powerful people are far more important than your political affiliation or your commitment towards a professional organization. You have to have afno manchhe be it a nearest kin group, business partners or committed followers of the affluent persons. If you have a strong association with a politically influential person, you can be appointed in a lucrative position, promoted without any hurdle and provided with good opportunities.

As a former university student and faculty member at the department of sociology and anthropology, I have also seen many cases of promotion and progress of such people. Among others, a nonmedical teacher with whom I had worked at the Institute of Medicine, Medical College and Teaching Hospital, in the late 1990s had good connections with the ruling party leaders. He was appointed vice chancellor of the university and again promoted to the chair of same university service commission. Another teacher, with whom I had opportunity to work, managed all possible promotions and opportunities within the university system of Nepal for fifteen years. Senior and academically proficient professors who do not blindly support any political party, however, still are just doing their teaching activities, and are waiting for bound retirement from university. If one 
evaluates the academic credentials and professional commitments, those who achieved and used their power to move up the university's hierarchy as were academically weak and poor performers.

Two examples, described below, suffice how an educated person develops his networks, changes political camps in search of better opportunity. After the comprehensive peace agreement between Seven Party Alliance (SPA) and United Communist Party of Nepal (Maoist), a professor of Economics from TU applied for party member to UCPN (Maoist). He requested concerned authorities for party membership. He was granted general membership of the UCPN (Maoist). He had thought that there were few educated person in the Maoist party and he would get political appointment after taking party membership. The UCPN (Maoist) won the 2008 Constituent Assembly elections by a large margin and got to lead the government. Chairman Pushpa Kamal Dahal (Prachanda) became the prime minister of Nepal. The professor requested to be appointed to a post like member of National Planning Commission or General Manager or executive chair of a state-run corporation, but was not successful in his attempts. Later, he gave up party membership and started back biting about the party for not honoring the people like him.

Similarly, another economist who became a member of the National Planning Commission during the minority government of CPN (UML) in 1994 and had been working as a think tank economist for the party and remained a committed party member for more than 20 years, resigned and joined the UCPN (Maoist). He was a very critical to the economic policy of Maoist prior to join the party. Currently, he is an economic advisor of UCPN (Maoist). The economists mentioned above didn't care much for political philosophies, they were far more concerned about building connections for personal gain and finding opportunities to be politically appointed to lucrative posts.

Generally, the afno manche is formed by developing social connections mainly on contextual basis. It may be a network of families, political parties and their sister organizations, caste and ethnicity, region, religion and specific cultural group. In many cases, multiple identities would work to form a strong link of afno manchhe.

\section{Classification of Afno Manchhe}

Afno manchhe is a complex social construct with many variations. In most existing studies, afno manchhe is discussed in general terms; complexity and differences between different types of afno manche are largely overlooked. Fan (2002) has described mainly three types of guanxi in China: family guanxi, helper guanxi and business guanxi. Quite similar categories can be created for afno manchhe in Nepal. These are: family afno manchhe, business afno manchhe, political afno manchhe and afno manchhe in bureaucracy. An aafno manchhe entering the room is always appreciated.

Family afno manchhe are expressive ties and instrumental ties based on kin relations. Business afno manchhe refers to the process of finding a solution to a business rather than personal problem by using "personal" connections. Political afno manchhe is linked to the particular political affiliation of a person and group, who benefits in the name of 'political affiliation'. These four types of afno manche are quite different in almost all aspects: nature, purpose, function and what is exchanged but at the same time overlap each other. If a person has a stronghold in all four types of afno manchhe, he would easily cash the better opportunity due to multiple linkages and social relations.

\section{Family Afno Manchhe}

Family afno manchhe is emotionally driven, affection is exchanged, in which immediate reciprocity is not always necessary. They are mainly related by blood or marriage. When a person is looking for help in Nepal, the first person to be requested for support or favor is often a relative or friend. Knowing influential people through kin or friendship is valuable in Nepal, because such relations tend to be more stable and reliable. The relations of kinship or friendship would 
impart a mutual obligation to help one another in times of need. The family afno manchhe is used for financial support, employment opportunities, admission of children in relatively competitive schools, quick access to doctors, introducing family members to local and national level leaders, and communicating with the person about the capacity of family members and relatives. Since this kind of afno manchhe is mainly blood or marriage based, its core values are affection, obligation and empathy, and reciprocity is not always necessary. The closeness of family afno manchhe would be strong, stable and permanent, unless there is misunderstanding or conflict between two kin groups. A university teacher describes this obligation as:

The concept of family afno manchhe works very well in Nepal. This is a good link to get moral and financial support, job, or get promotion in public as well as private organizations. This is a kind of reciprocal relationship. If one is in difficult situation but does not get help from afno manchhe, s/he is no more afno manchhe. If one has a politically powerful and economically strong family afno manchhe, he will have an easier time getting ahead in life. People take pride in having such familial connections.

There is a saying in Nepali that 'afno manchhe vaneko afno nai ho' (one's inner circle remains own). If the person does not get help from afno manchhe but gets an opportunity from the outer circle then it is said that 'tadako manchhe afno vayo tara afno manchhe afno huna sakina' (a far away person become ours but the nearest one could not). People usually mention relatives as their closest afno manchhe. Kinship bonds would naturally create the stronger obligation. Remarking on the situation of Nepali NGOs, a sociologist mentioned:

Non-governmental organizations (NGOs) in Nepal have strong influence from village level activities to national level social and political activities, including formulation of government plans and activities of various political parties. They can influence state policy. If one sees the history of organizational structure of NGOs, more than 90 percent of these institutions are managed by few members and their nearest relatives. They give job opportunities to their own afno manchhe, hire another afno manchhe as the auditor of the organization, and fire unrelated employees on the pretext of poor performance. The ultimate objective of this network is to make stronghold in the organization by a handful of family members. Such network of afno manchhe would also help protect the privacy and weaknesses of the organizations.

If one explores some positions like advisor(s), chairperson, executive director, treasurer and program coordinator of financially sound NGOs in Nepal, and their genealogical links and relations, a very clear picture of their relationship can be traced. In such a situation, family afno manchhe is not limited to emotional affection and exchange, but also economic support and institutional favor.

Andersen (2004) in a seminar paper entitled 'What a Village Can Tell - Democratization in Nepal' mentions that peasants adopts various strategies of survival in order to cope with resource scarcity and vulnerability that they face. Included among these strategies are the creation of relations with those who are more privileged and can provide access. When a poor villager is looking for help, the first person he asks is often a relative or friend. Knowing influential people through kin or friendship is valuable in a volatile environment, because such relations tend to be more stable and reliable than other types. Andersen (2004:6) further says:

The relationship of Afno Manchhe was here described as an 'inner circle' in which members should protect the closed, social relationship both by following the norms involved and by protecting it against hostile outsiders. In the selected villages there were several such 'inner circles'. Villagers 
would usually mention relatives as their closest Afno Manchhe. Kinship bonds would - naturally - create the stronger obligation. As one noted, 'My relatives are closer to me, and then friends, then comes the Ward Chairman'. Another villager explained, similarly, that 'for me all [of these] are Afno Manchhe, but our brothers are closer. In case the brothers are not there then friends are the closer, and if friends [are not there] then the neighbors... then comes the Ward Chairman'(emphasis is original).

The closest family afno manchhe are immediate family members, followed by closest extended family, close friends who are also treated as family and people with shared experiences such as playmates or classmates. Both the paternal and maternal kinfolk can play an important role in developing a link of family afno manchhe. If one is successful in developing the network of afno manchhe within a powerful kin group, it would not be difficult to land a job, to get a promotion, or transfer to better locations or posts. Favors done by family afno manchhe are expected to be returned by some means but by no specific date. One can easily see the deep familial connections in almost all political parties in Nepal, also termed as 'the kitchen cabinet' where major appointments and decisions are informally discussed and decided. In such situations, historical contribution of many party cadres are ignored, meritocracy is sidelined ${ }^{2}$. In Nepal, the family afno machhe is also very strong in private job and part-time or

\footnotetext{
2 In October 2009, Prime Minister (PM) of Nepal, Madhav Kumar Nepal promoted Foreign Minister Sujata Koirala, the daughter of Girija Prasad Koirala - Former Prime Minister of Nepal and the then President of Nepali Congress (NC), as the Deputy Prime Minister, despite criticisms within Koirala's party. NC President had long been exerting pressure on the PM to appoint his daughter as Deputy PM. Media quoted that sources close to PM office said the PM took decision under pressure from NC President. Congress Spokesperson Arjun Nar Singh KC had said with the media as "This is not an institution decision of the party; the party is unaware about the appointment."
}

contract appointment in public institutions which becomes easier to legitimatize as a full time staff after few months or years. One can easily find both teaching and non-teaching staff at different universities and colleges, people in different departments of private organizations and public institutions who are closely linked to family afno manche.

This sort of family afno manchhe is a social capital which consists of prestige and renown attachment to a family and name (Bourdieu 1977). This is often the only legitimate way to accumulate resources and take advantage of connection or social position and trust. There is also a tendency to protect people whom you know better, or have blood ties with. If kinship ties and affection exist, the person will not be fired even if the person commits a grave mistake.

\section{Business Afno manchhe}

Business afno manchhe is the product of current political and socioeconomic systems; utility-driven, a deal of money and power. In terms of quality, family afno manchhe is stronger, more stable and requires long term commitment. Business afno manchhe, on the other hand, is characterized as tactical, opportunistic and unstable. There is little trust and commitment in the business afno manchhe relationship. The only thing that matters to the parties is their own business ${ }^{3}$. Thus, it is the exchange or deal between money and power.

\footnotetext{
3 Padma Jyoti, an industrialist of Jyoti Group, was nominated as a Constituent Assembly (CA) member by the UCPN (Maoist). Binod Chaudhary, head of the Chaudhary Group was nominated by CPN (UML). Chaudhary, in an interaction program in a television program, argued that the CPN (UML) is pro-business with more socialist than communist leaning. Likewise, Rajendra Khetan from the Khetan Group was nominated by Communist party of Nepal Marxist Leninists (CPN-ML). If one looks at the constitution of these three communist parties, a clear political difference can be highlighted. On the other hand, the mission, vision and business strategies
} 
In business afno manchhe, the main strategy is finding business solutions through personal connections and developing a win-win situation. Its cultural and social root is weak legal system, and base is social or through intermediary with core values of power influence. The motivation for such network is to overcome bureaucratic obstacles and get special treatment/protection. The exchange is basically for money and power with the condition of strictly reciprocal 'gain and loss' bargaining. ${ }^{4}$ The quality of closeness varies and depends on the existence of other factors which are more elastic and situational.

Some people may argue that experience is vital to the potential family-member hire. They feel the family member should establish his or her own competence and professional sense of worth before assuming work responsibilities within the family's firm. Testing and honing his or her skills and abilities allow one to bring expertise to the enterprise and make the appointment a success. The key is to have clear criteria for the job and to apply it consistently for all candidates, neither favoring nor discriminating against family members. Furthermore, people chitchat that families rely on multiple incomes for their standard of living, the ethical and pragmatic considerations regarding nepotism must be carefully negotiated to ensure the most effective overall business strategy. However, nepotism in business afno manchhe in private sector can lead to success if applied appropriately, or turn disastrous if applied without careful consideration of all the variables involved.

of these three industrialists are the same. The only difference is that they were nominated in the political sphere from different political parties.

${ }^{4}$ Everyone in Nepal can see the mechanism which people employ to get their work done through the broker or middleman. They are confined to specific location or sector and do not have enduring relations with the clients but are permanent channel to get things done. This can be seen, for example, mainly in Office of Land Revenue and Management and Transport Management Office.
In a country like Nepal, which is characterized by 'low professional morality' and 'social responsibility' and a 'weak legal system', emphasis on afno manchhe and exchange of favors within relationships are characterized by obligation and indebtedness. Regarding the decision to allow India to print Machine Readable Passport (MRP), the then Prime Minister Madhav Kumar Nepal told the Public Accounts Committee that the government awarded the contract due to "political reasons, diplomatic relations with India and time constraint.” The cabinet decision was withdrawn after heavy criticism from opposition parties, civil society members and political analysts.

The business afno manchhe in Nepal supports for the solutions to business rather than personal problem. Two types of connection can be seen in business relationship; business-business and business-government officials. Business-business afno manchhe helps mainly for expansion of business and creating trust with each other, whereas business-government official relations helps to bypass laws and regulations through personal connection with government officials and/or to obtain special treatment. Commission, bonus and share are some of the economic offers and special gifts are provided for such undue advantages. Fan (2002:374) mentions that business guanxi has a notorious reputation in China as it refers to the use of someone's authority to obtain political or economic benefits by unethical persons.

Though the business is transaction based, it is also relationship-based. A successful Nepali business person would be described as being well connected. Afno manchhe network is a valuable source of information for the amount to be quoted and documents to be submitted in various tenders, consultancy work, and supply of equipments announced by the government as well as the private sector. These information are of strategic importance for getting such contracts. Almost all major political parties of Nepal have developed a covert link through bureaucrats in ministries and related line agencies, from the office of the Prime Ministers to the office of Village Development Committees (VDCs). The person who 
has family, political and business links with the authority get larger amount and accurate information compared to others. In many cases concerned people do not inform and communicate properly about ongoing activities of organizations. By monopolizing the information one can influence by channeling favor to and from others.

If one tries to analyze the relationship between the scholarship granted for higher education and higher administrative occupations of the parents or close relatives, a perfect correlation can be traced. During my interaction with former high level bureaucrats they confessed that selection of scholarships provided to the government of Nepal, selection of the training participants in developed countries, and consultants to be hired for special work are not transparent in almost all ministries of Nepal. They also admitted that information are kept secret for their own benefit, and not disseminated to the targeted people. In an interaction of policy and implementation issue in Kathmandu, many respondents mentioned that Nepal has made good policies in many fields but these policies are implemented 'only in papers'. Paper implementation is required for the donors because much of the monitoring and evaluation in Nepal are focused on the paper trail. The paper work in file cabinets plus manuals on shelves do not equal with benefits to the ordinary people.

Another example of business afno manchhe can also be clearly seen in the doctor and pharmaceutical companies relationship in Nepal. Bonus and special incentives are offered to the doctors who prescribe the products of specific companies, be it Nepali, Indian or multi nationals. Gift items and financial support that are generally offered include: carpets, pens, blankets, bed sheets, iron, calculator, $\mathrm{TV}$, airfare for international conference, food expenses for national level conference. Some companies also provide surprise gift on birthdays of family members of the doctors (Subedi 2009). The cost of undue expenses of the pharmaceutical companies has to be incurred by the poor and sick Nepalis. The business afno manche has a strong network power to mobilize opportunities and resources.

\section{Political Afno Manchhe}

Politically afno manchhe is linked with the political ideology of an individual or the group where a special relationship is developed based on shared political attributes and network of social connections. For a person looking for job, his party affiliation affects the selection process. Connection with political parties and link with powerful afno manchhe within the party is crucial for exercising power in Nepal. During an interaction with TU teachers, they said:

Party connection is very important to get political appointment. University teachers get best teaching award not because they are the best teachers but because they have a good networking with political parties in Nepal. The current Vice Chancellors of Tribhuvan University is afno manchhe of CPN-UML, Sanskrit University is afno manchhe of Ne CPNUML and Purbanchal University is afno manchhe of Unified Maoist. Likewise, all the key posts in the university, including, Campus Chief were allotted based on Bhagbanda (quota of major political parties) of afno manchhe of three major political parties.

After the political change in Nepal in 1990, and in the current political transition phase, the concept of afno manchhe in various appointments has been very strong and influential. At the university level, for example, Vice Chancellor, University Grant Commission, Service Commission, Dean, Research Division Heads are appointed based on the quota of political parties. Within the political party, a person who implements the order of political leader is given fair priority compared to other critical sympathizer. Thus the merit based ramro manchhe (good person) does not get place in proper position and politically affiliated hamro manchhe (our person) has been very strong in almost all political and social spheres. A written letter from the powerful political would represent one of the most important 
introductions as the foundation for strong relationship within the party ${ }^{5}$.

Appointing a politically afno manchhe is crucial to provide various opportunities within the institution. The concept of hamro manchhe (person from the same party or even from the same faction of a political party) has been very strong in every sphere of life in Nepal and the concept of ramro manchhe (good or competent person) has been nonessential. There is hardly any ideological differences between Sushil Koirala and Sher Bahadur Deuba in Nepali Congress, between Jhalnath Khanal and Madhav Nepal in CPN (UML), and between Puspa Kamal Dahal and Babu Ram Bhattarai in UCPN (Maoist). They are aware that the political linkage and appointment of afno manchhe may carry with its great advantages accessing scarce resources afterwards. Similarly, the government has not been able yet to recommend 26 members to the constituent assembly (CA) and the CA is incomplete almost six months after the election was held. Furthermore, political parties and their sister organizations engage to justify such appointment and to influence decisions in situations defined by impersonal bureaucratic rules.

The constitutional ${ }^{6}$ and other major political appointments are based on the affiliation of major political parties to get undue political

${ }^{5}$ I had an opportunity to talk with the former Dean of Institute of Medicine, Tribhuvan University. He mentioned that the hospital is being used as a 'job bank' by each successive government. He mentioned that none of the staff of the hospital are transferred out but new staff keep joining the hospitals mostly in the administration section. He further mentioned, "In university system, Vice Chancellor, Rector and Registrar before the expiry of their terms, bring in their own people to the hospital.” The hospital staff gets 50 percent extra salary every month. They also get ninety percent discount in treatment for their family members in the hospital including the medicine.

6 Due to political interest of various political parties and unstable government, the head and other members of the constitutional body become vacant for a long time in Nepal. The major political have their vested interest to influence major decision and activities from afno manchhe. They blame to each other but all the political parties have the same vested interest, to advantages from these organizations ${ }^{7}$. Most of the leaders who are in power have little time or interest to the public. They are very much concerned on political game, individual and party benefit issues and misuse of power. One the other hand, the audio, visual and printing media which are expected to provide impartial messages are very weak and extremely biased because of their affiliation to one or another political party.

\section{Afno Manchhe in Bureaucracy}

Max Weber argues that the modern organization of civil service separates the bureau from the private domicile of the officials, and in general, bureaucracy segregates official activity as something distinct from the sphere of private life (Weber 1999 [1946]). In principle, the executive office is separated from the household, business from private correspondence, and business assets from private fortunes. Bureaucracy is also called as a 'permanent government ${ }^{\prime 8}$. It is also said that the success and failure of any government depends on the quality, mechanism and the nature of support of bureaucracy. An 'ideal type rational legal' bureaucratic model should have the

delegate authority to their afno manchhe from legally instituted powers.

${ }^{7}$ In March 2012, the government headed by Dr Baburam Bhattarai, Deputy Chairman of UCPN (M), had decided to provide Rs. 20 million as financial assistance to the UCPN (Maoist) team including party Chairman Pushpa Kamal Dahal's son Prakash to scale the Mount Everest. Maoist cadres had said that their journey from Lumbini to Mt Everest is aimed at exerting pressure on the leaders to conclude the peace and write the constitution on time. It was a question of fairness. The decision followed heavy criticism against Dahal's son for fishing state money to climb the world's highest peak. The team, however, did not take the money from the government saying that the respect of sentiment of Nepali people.

${ }^{8}$ The management of the office follows general rules, which are more or less stable, more or less exhaustive, and which can be learned. Knowledge of

these rules represents a special technical learning which the official possess (Weber 1999:106) 
characteristics of political neutrality, hierarchical composition, specialized task and knowledge, formal communication and record management, and objective standards and impersonal rules that ensure organizational reliability and predictability.

Management in the bureaucracy is highly personalized in Nepal. Formal rules governing recruitment, promotion, transfer and dismissal of public officials are rarely followed. With the change in government or with the change in the minister, reshuffling of the bureaucracy is very common. There is a Nepali saying, 'hamro manchhe' (our person) is preferred over 'ramro manchhe' (good person), and thulo manchhe (big person) is preferred over 'sano manchhe' (small person) (Dix 2011).

In Nepal, however, public administration operates within a particular administrative culture that directing and determining its functioning. Almost all bureaucrats are under the umbrella of political organizations in the name of professional organization ${ }^{9}$. During the interaction with the people working in government offices, it was frequently stated by the participants that their confidential performance rating system have had created fear of undue discrimination among civil them. It has been depriving the civil servants of knowing the rating of their performance on the job by their supervisor, and also have not been getting the opportunities to know the way improving their performance. It was also mentioned that the phenomena of confidential rating has encouraged sycophancy and chakari. In such a situation rewards and punishments are not related

\footnotetext{
${ }^{9}$ Report of the parliamentary committee comprising the top leaders of major political parties has shown that employees' associations are functioning like sister organizations of the political parties. The leaders of the employees unions have a decisive say in matters such as placement in lucrative jobs, selection of heads of the key Ministries and departments. Many civil servants say that the top leadership in the civil service is found more keen and receptive to please the unions leaders than the general public. These bureaucrats do not hesitate to fulfill their irrational and non-professional demands (Tiwari 2009:20-21).
}

to performance. Tiwari (2009:22), for example, quotes the civil servants remarks as;

....while at work if you take special care of the powerful clients, your performance in terms of quality of service, non-delivery of services and non-responsive behavior to the client common people does not matter, it is excused. It will not meet any punitive action.

The tendency to see what pleases the higher officials becomes the prime concern of civil servants rather doing their job honestly for benefiting the ordinary people. An informal practice in which an authority holder exhibit special preferences towards kinfolk and family members, party cadres and secures substantial prerogative and profit for certain families, clans or some social subgroups is called natabad, nepotism. Similarly, kirpabad, favoritism is a mechanism of power abuse implying a highly biased distribution of state resources, no matter how these resources have been accumulated. It is a tendency to favor anybody those who are supposed to be close and trusted; be it based on familial, ethnic and geographical- origin or a friend or just a particular group10. These are seen in the form of natabad and kripabad' in the Nepali public administration (Poudyal 2009). Interference from political leader administration has

${ }^{10}$ Media quotes many times that Nepotism, favoritism, and corruption are common especially in the transfer and promotion processes in Nepal Police (NP) and many police officers believe that they personally have been 'denied professional opportunities because they did not pay bribe or lacked family or friend connections. During the interaction with university students, participants frequently mentioned that lack of accountability, political interference, and corruption are the factors contributing to an ineffective chain of command in the NP. On the interaction, police officials attributed political pressure as the main reason for their inability to provide satisfactory security to the public. 
undermined the impartiality, neutrality and accountability, the core values of bureaucracy.

\section{Multiple Connections}

As a single process, afno manchhe refers to the personal interactions between two individuals. However, this is not the case all the time. A person searches as many as afno manchhe to get favor. S/he tries to maintain as much as connection in order to get favor. For example, a person tries to get favor from a person who is powerful as a opposition party leader from kin relationship. On the other hand, s/he tries to get favor from ruling party as an active member of ruling party professional organization. This is exactly what afno manche works, as a multi-path process. Relationships, strong or weak, exist all the time. Thirdly, afno manchhe involves a series of activities mostly preplanned and carried out between two or more parties in the afno manchhe network. Such activities can include anything from having a meal together, to gift giving or doing a favor. But usually it is just a circle of mutually supporting associates, whose personal ties cut across and through the supposed impersonalities of bureaucracy. Adam (1998:39) writes, for example:

If one needed any sort of privilege from a ministry, one would consider if one had afno manchhe in that ministry on whom one could rely for processing one's request. If no family connection existed, one might consider chakari to create a basis for obtaining favors from a status superior. These family relations were usually the most promising sort of afno manchhe, but beyond that person's who were in one's caste or ethnic group, and after them cultivated friends who could be brought into a morally obliged sense of duty, as would be true in the family, were sought. Thus creating afno manche relationships through marriage, politics, and a multitude of social events (worship events, parties, gambling, social clubs, sports, hobbies, etc) was a primary strategy for economic, political, and social mobility.

Nepali people remember for a long time a favor that was given to them when especially was needed. They share such happy events with their afno manchhe. When a favor is returned, it is highly valued. A person connected as family afno manchhe also tries for business and political afno manchhe. This can be seen very openly in family and politics in different parties. Some family members strategically join another political party to take advantages from other political parties and for social security.

Much goodwill can be generated if a person has all four types of connection- family, business' politics and bureaucracy. This would become strong, permanent and influential. Social networks and trusts are considered the key markers for upward social mobility. One has to be politically and economically influential to utilize the afno manchhe network. If a person does not have even a single connection would be frustrated, fell inferior due to unfair evaluation mainly in the job market and try to search for alternative livelihood strategy. Unable to develop a social connection for better job is one of the main causes of brain drain from Nepal.

\section{The Relationship between Afno manchhe and Corruption}

From head of the state to a person waiting on a queue to get a liter petrol for his motor bike, and a farmer who waits long hours to get few kilogram of chemical fertilizer recognize that corruption is a serious problem in Nepal.

As stated earlier, afno manchhe is a network of connections between or among family and kinship ties, business linkages and party affiliation. This is similar in case of guanxi. In a society with a long tradition of rule by a group of people instead of rule by law, having good guanxi with officials has always been vital. Corrupted guanxi and guanxi-based corruption are like conjoined twins that cannot be separated (Fan 2002). It is safe to say that there is no business afno 
manchhe in Nepal and guanxi in China network that is not tinted by corruption and there is no corruption without using afno manchhe or guanxi. Thus, there are both legal and social aspects to the concept of the corruption. The legal analysis of corruption is not sufficient to understand the nature and processes of corruption.

People in bureaucracy and business enterprises feel compelled to honor moral obligations that contradict the legal rules for proper behavior in these organizations, or even worse be tempted to gain private individual benefits by giving benefits to those who offer attractive gifts. It is when this occurs that we enter into the muddy waters between gunanxi and fubai, corruption (Haaland 2010:15). In Nepali, it is called ghush, a fixed sum, a certain percentage of a contract, or any other favors in money or kind, usually paid to a state official who can make contracts on behalf of the state or otherwise distribute benefits to companies or individuals, businessmen and clients (Subedi 2005). In this sense fubai and ghush are comparable words.

Research based on analyses of corruption indices across countries suggest that increased economic competition and economic growth are negatively related to corruption. Structural factors and corruption may also mutually reinforce each other (Jancsics 2014). In contrast to the findings that economic competition reduces corruption at the country level, the literature in organization studies emphasizes that an intensely competitive environment can drive organizational members to engage in misconduct, rule-breaking, and corrupt activities (Jancsics 2014). Here, the competition for customers, contracts, and other limited resources lures organizations to pressure their employees to behave illegally by setting unrealistic financial and sales goals.

Relational models examine illegal activities by focusing on interpersonal connections such as non-monetary forms of exchange, reciprocity, favors, and other interactions between corrupt actors at the small group level. The main premise of the relational perspective on corruption is that individuals associate with one another because they profit from their associations. Personal social networks that are based on long term social relationships allow individuals to deal with inadequate formal institutions, the imperfections of state or marketdominated socioeconomic systems.

Corruption in Nepal has become so prevalent that it becomes the way of life of the society. Afno manchhe meant to obtain scarce consumer goods or to find a better job for one's children through the "back door". Today, afno manchhe is implicated in all big corruption cases and organized crimes. One particular feature is that corruption has evolved from individual wrong doings into institutionalized corruption that often involve a complicated afno manchhe network between high-ranking officials, businessmen, army or police and mafia. The recent case in Sudan Ghotala (scam) is an example. Corruption can be found in any country or economic system, but it is afno manche that provides a fertile soil in Nepal for corruption to flourish. Each government has waged and lost every anticorruption campaign ${ }^{11}$ as new "worst" cases are constantly emerging.

$$
\begin{aligned}
& \text { Money } \leftrightarrow \text { Afno manchhe } \leftrightarrow \text { Power } \rightarrow \text { Money } \rightarrow \text { Corruption } \\
& \text { Corruption } \rightarrow \text { Money } \leftrightarrow \text { Afno manchhe } \leftrightarrow \text { Power } \rightarrow \text { Money }
\end{aligned}
$$

11 On 2 August 2011, to support the good work of Commission of Investigation of Abuse of Authority (CIAA), around 300 activists gathered outside CIAA with different message and slogan in their t-shirts and banners including the senior and popular comedy duo Maha Jodi, Madan Krishna Shrestha and Hari Bansa Acharya, Rabindra Mishra (Senior Journalist of BBC Nepali Service), Rameshwor Khanal (Former Finance Secretary) and Sadichha Shrestha (Miss Nepal 2011). After silent standing gather for half an hour outside the CIAA building, the Secretary of CIAA Bhagwati Kafle and other officials welcomed and joined the group where they were presented a T-Shirt printed 'Bhrastachari Lai Kira Paros' (May the corrupt rot). The team also handed over the T-Shirt to the Prime Minister Dr Babu ram Bhattarai. Talking to the team, Dr. Bhattarai reiterated his zero-tolerance to corruption policy and pledged to prioritize and tackle corruption while also encouraging such civic movements to continue. 
The concept of afno manchhe is unfair to the people who are more qualified. On the other hand, issues against corrupt people have been started at expose their activities and cases are filled in Supreme Court. People have started to say that it is not only the job of government to be accountable, as a citizen we have to fulfill our responsibility. Furthermore, they have been saying that it is better to live simple life than to own a big house or a car by corruption.

This will lose the competent human resources and promote frauds, dissatisfaction among the employees and lower morals of employees, create problems in maintaining disciplines and breach confidentiality. If highly qualified people are deprived of what they deserve they feel very bad and that may cause increment in brain drain. The afno manchhe supports the 'back door' process to involve less competent person.

\section{Conclusion}

Culture, the way of life of people with certain values and practices, is developed and modified to cope with the problems people face in their daily life. The reasons for selecting this topic was to highlight 'what has been happening on day-to-day life of Nepali people and how to they try to cope with the problem they face' rather 'what should be the ideal, social just, democratic, equity based Nepali culture'. The informal patterns of interaction that has been practiced and regulated with strong network in day-to-day actions has been getting social legitimacy which are part of habitual action. The broader concept of afno manchhe has been discussed to portray its type, function and strategic games which range from moral obligation to high level corruption. It is easier for strong network position people to develop afno manchhe relationship with any particular individual and those in weak network positions must try harder. There is a little doubt that afno manchhe will remain an important area for further research. There is also a room for further theoretical development.

\section{Acknowledgements:}

A slightly different version of this paper was presented in the International Symposium on "Guanxi in Symbolic and Interactional Contexts”, jointly organized by the School of Social Development and Public Policy at Fudan University and the Nordic Center at Fudan (October 25-26, 2011), Shanghai, China. I am indebted to Professor Gunnar Haaland for his academic input. This paper would not have been in this form without his support and encouragement. I am grateful to Fan Lizhu, Professor of Sociology and Associate Dean, Fudan University for inviting me in the symposium.

\section{References}

Adams, Vincanne (1998). Doctors for Democracy: Health Professional in the Nepal's Revolution. London: Cambridge University Press.

Andersen, Hans Gorm (2004). 'What A Village Can Tell Democratization in Nepal'. A Paper for Panel 21 presented $17^{\text {th }}$ European Conference on Modern South Asia Studies, Lund, Sweden (6-9 July 2004).

Bista, Dor Bahadur (1991). Fatalism and Development: Nepal's Struggle for Modernization. Hyderabad, India: Orient Longman Limited.

Bourdieu, Pierre (1977). Outline of a Theory of Practice. Cambridge: Cambridge University Press.

Chang, Win-Chin (2004). Guanxi and Regulations in Networks: The Yunnanese Jade Trade between Burma and Thailand, 196288. Journal of Southeast Asian Studies, Vol.35, No.3, Pp 479501.

Dix, Sarah (2011). Corruption and Anti-corruption in Nepal: Lessons Learned and Possible Future Initiatives. Oslo: Norwegian Agency for Development Cooperation.

Dunfee, Thomas W. and Danielle E. Warren (2001). Is Guanxi 
Ethical? A Normative Analysis of Doing Business in China. Journals of Business Ethics, 32(3): 191-204.

Fan, Ying (2002). Guanxi's Consequences: Personal Gains at Social Cost. Journal of Business Ethics, 38(4): 371-380.

Haaland, Gunnar (2010). Reflection on Contrasting Views on Themes in Chinese Civilization. Dhaulagiri Journal of Sociology and Anthropology, 4: 1-20.

Jancsics, David (2014). Interdisciplinary Perspectives on Corruption. Sociology Compass, 8/4:358-372.

Macfarlane, Alan (1993). Fatalism and Development in Nepal. In Michael Hutt (ed.) Nepal in the Nineties (pp 106-127). New Delhi: Oxford University Press.

Millington, Andrew, Markus Eberhardt and Barry Wilkinson (2005). Gift Giving, "Guanxi” and Illicit Payment in Buyer-Supplier Relations in China: Analyzing the Experience of UK Companies. Journal of Business Ethics, 57(3): 255-268.

Park, Seung Ho and Yadong Luo (2001). Guanxi and Organizational Dynamics: Organizational Networking in Chinese Firms. Strategic Management Journal, 22 (5): 455-477.

Pfaff-Czarnecka, J. (1997). Vestiges and Visions: Cultural Change in the Process of Nation Building in Nepal. In Gellner, D. PfaffCzarnecka and J. Whelpton (eds), Nationalism and Ethnicity in a Hindu Kingdom: The Politics of Culture in Contemporary Nepal, pp.419-70. Amsterdam: Harwood academic publishers.

Poudyal, Shiva Ranjan (2009). Dynamics of Formal and Informal Institutions shaping the administrative culture: A case of Nepalese public administration. An Unpublished Thesis Submitted to Institute of Social Studies, the Netherlands.

Regmi, Mahesh C. (2002). Nepal: An Historical Miscellany. Delhi: Adroit Publishers.

Smart, Alan (1993). Gifts, Bribes, and Guanxi (1993). Cultural Anthropology, 8(3):388-408.

Subedi (2001). Medical Anthropology of Nepal. Kathmandu: Udaya Books.
Subedi, Madhusudan (2005). Corruption in Nepal: An Anthropological Inquiry. Dhaulagiri Journal of Sociology and Anthropology, 1: 110-128.

Subedi, Madhusudan (2009). Trade in Health Service: Unfair Competition of Pharmaceutical Products in Nepal. Dhaulagiri Journal of Sociology and Anthropology, 3: 123-142.

Tiwari, Madhu Nidhi (2009). Governance Reform in Political Transition: The Case of Nepal's Civil Service Reform. Nepalese Journal of Public Policy and Governance, 24(1):127.

Weber, Max (1999) [1946]). The Bureaucratic Machine. In Charles Lemert (ed.) Social Theory: The Multicultural and Classical Readings. Westview Press. 